\title{
The Relationship between Grammatical Metaphor and Translation from Chinese to English: An Empirical Study Based on a Personal Experience Narrative Text
}

\author{
Jiangping $\mathrm{Zhou}^{1}$ \\ ${ }^{1}$ School of Foreign Languages, China West Normal University, Nanchong, China \\ Correspondence: Jiangping Zhou, School of Foreign Languages, China West Normal University, No.1 Shida Road, \\ Nanchong, 637009, China. Tel: 86-817-251-5650.E-mail:zhoujiangping163@163.com
}

Received: December 18, 2015 Accepted: December 30, 2015 Online Published: January 31, 2016

doi:10.5539/ijel.v6n1p171 URL: http://dx.doi.org/10.5539/ijel.v6n1p171

This paper is financed by the Department of Education of Sichuan Province, China (Project No. 13SB0307).

\begin{abstract}
Grammatical metaphor is one of the important theories in Systemic-Functional Linguistics. Through an empirical study, this paper analyzes the correlation between grammatical metaphor and its sub-categories and the translating quality of personal experience narrative texts from Chinese to English, and the findings show that grammatical metaphor, especially ideational metaphor, and translating quality are significantly positively correlated. Through analyzing the differences of grammatical metaphor and its sub-categories used by learners of English from different proficiency levels, and the findings show that grammatical metaphor and its sub-categories are significantly different except textual metaphor.
\end{abstract}

Keywords: systemic-functional linguistics, grammatical metaphor, translating quality, empirical study

\section{Background Information}

Grammatical metaphor or GM, which was firstly proposed by M. A. K. Halliday in his book Introduction to Functional Grammar in 1985, is one of the most fundamental theories in Systemic-Functional linguistics. According to Thompson, GM occurs when a lexicon-grammatical form does not denote its usual meaning (Thompson, 2004). Liu (2007) classified GM and its subcategories in details (Figure 1). Owing to the limitation of GM internal attributes, related researches of GM are practically focused on ideational metaphor. The metaphorical expression of ideational domain contains two kinds of grammatical changes, i.e. "one is the changes of ranks, the other is the changes of structures (Halliday, 1998)." In line with grammatical changes, researchers classified ideational metaphor from two different aspects. One classification realized the semantic units of sequence, figure, and element by rank-shifting metaphorically. The other classification was based on the metaphorical changes from one semantic element to another semantic element. As to the second classification, Halliday (1998) proposed eleven major GM categories, which correspond to the eleven possible changes between five semantic elements and two minor GM categories (Yang, 2008).

There are not few examples to apply GM to the study of translation. Foreign scholars are mainly Hatim \& Mason (1990, 2001), Bell (1991, 2001), and Baker (1992, 2000). Home scholars also approached to this field (Huang, 2006, 2009; Wang, 2006). However, there are very few empirical studies about GM. The reason might be the speculativeness of GM and it is also difficult to approach it empirically. To our delight, there are scholars (Derewianka, 1995; Galve, 1998; Ravelli, 1985, 2003; Byrness, 2009; Yang \& Sun, 2012), presently, who are working on this aspect (e.g.: The textual interplay of GM on nominalization occurring in written medical metaphor; Emergent L2 German writing ability in a curricular context; the use of cohensive devices in argumentative writing), and opening a new vision for the empirical study of GM. 


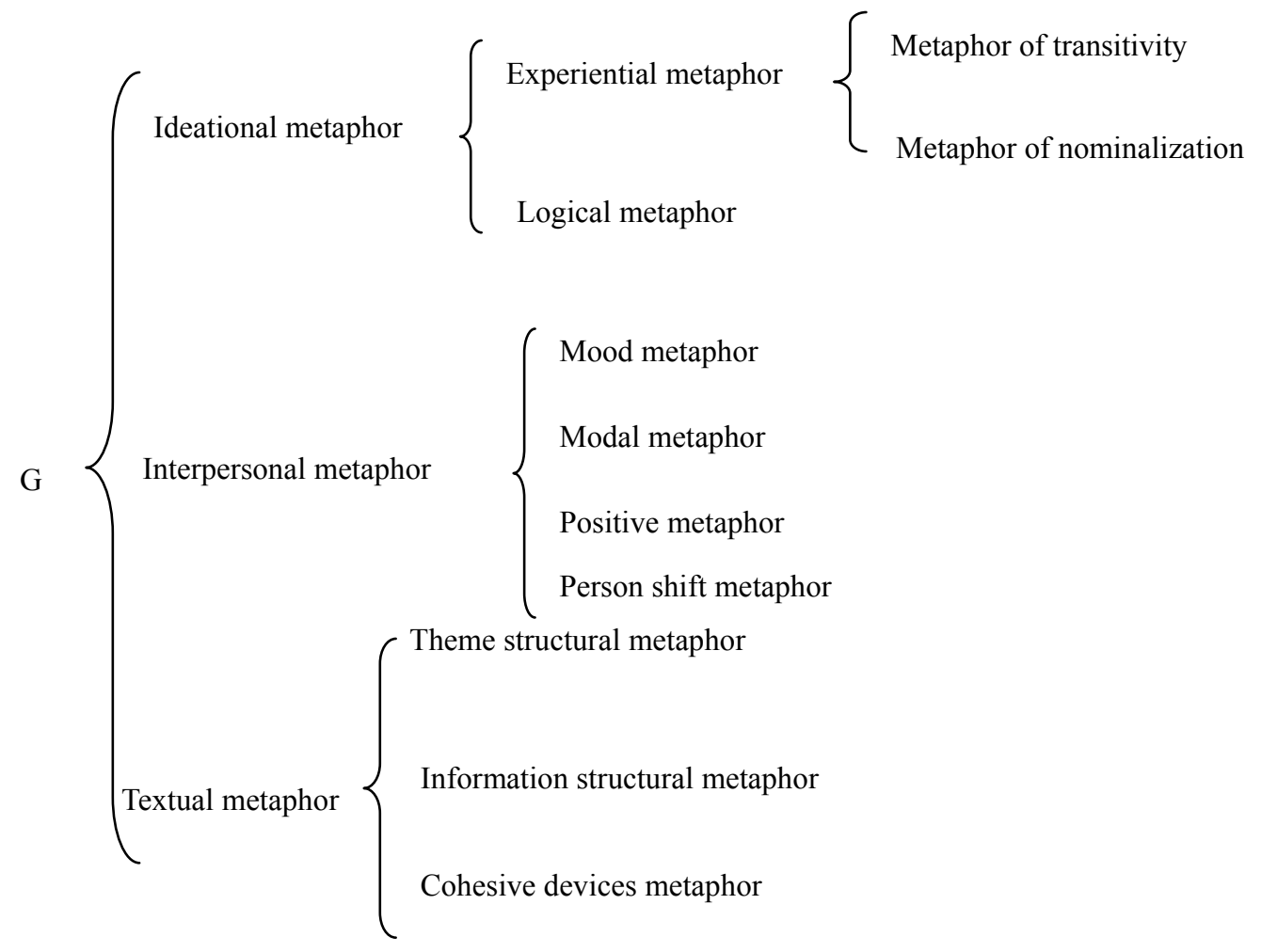

Figure 1. Classification of GM (Liu, 2007)

There are not few examples to apply GM to the study of translation. Foreign scholars are mainly Hatim \& Mason (1990, 2001), Bell $(1991,2001)$, and Baker $(1992,2000)$. Home scholars also approached to this field (Huang, 2006, 2009; Wang, 2006). However, there are very few empirical studies about GM. The reason might be the speculativeness of GM and it is also difficult to approach it empirically. To our delight, there are scholars (Derewianka, 1995; Galve, 1998; Ravelli, 1985, 2003; Byrness, 2009; Yang \& Sun, 2012), presently, who are working on this aspect (e.g.: The textual interplay of GM on nominalization occurring in written medical metaphor; Emergent L2 German writing ability in a curricular context; the use of cohensive devices in argumentative writing), and opening a new vision for the empirical study of GM.

\section{Experiment}

\subsection{Research Questions}

The purpose of this experiment is to analyze the functions of GM and its subcategories. Thus, this paper attempts to analyze the relation between GM and its subcategories and the translating quality from Chinese to English among English learners of different levels. The following two questions are mainly concerned:

What is the relation between GM and its subcategories and the translating quality from Chinese to English?

Is there any difference among English learners of different levels while translating from Chinese to English about the use of GM and its subcategories?

\subsection{Participants}

Undergraduates $(\mathrm{n}=30)$, majoring in English literature, and postgraduates $(\mathrm{n}=30)$, specializing in English linguistics, took part in the experiment. Participants were recruited from a translation course at China West Normal University in fulfillment of a credit requirement. They were told that their translation samples would be applied to an experiment.

\subsection{Materials}

All undergraduates and postgraduates were required to finish translating the following personal experience narrative into English within 60 minutes (Zhou, 2010). A personal experience narrative text refers to a narrative that describes the narrators' personal experiences, such as fright, unforgettable experiences etc. This paper mainly focuses on the unforgettable experiences, because the study of personal experience narratives has received much attention in recent years, and has become part of the work together with language production. More importantly, 
Labov's (1972) conclusion of each narrative's six subcategories, that is, coda, orientation, complicating action, result, evaluation and coda, will facilitate participants' translations.

“得肺炎的那段经历是我最难忘的一段经历。在2003年, 正是“非典”在中国全面爆发的时候, 我得了急性 肺炎。大概在那天晚上 12 点左右,

我发烧得很厉害, 然后到医院求医, 量了体温之后, 医生告诉我我39.5度。由于发烧时间过长, 便烧成 了肺炎。在这个非常时期，我的典型肺炎吓倒了很多人，因为他们都以为我是“非典”。

经过一周多的输液治疗, 烧退下来了, 并且肺上的炎症也消失了。这段经历在我心中留下了深深的记忆 。现在想起来都还有一种后怕。”

The most unforgettable experience is the one I once suffered from Pneumonia. In 2003, while I suffered from Pneumonia, it was also the time that the SARS was breaking out in China. About 24 o'clock that day, I got a very high fever. The doctor told me that my temperature was as high as 39.5 degrees. Because of the long time of high fever, I suffered from Pneumonia. My illness made many people feel frightening during this special period, because they had thought that I suffered from the SARS. After more than one week's injection, my high fever returned to normal and the Pneumonia was cured, too. The experience has been inscribed into my heart deeply. I fear after the event when I thought of it (taken from one of the 60 samples).

\subsection{Data Collecting}

Firstly, all the translating samples were scored. The standard complied fully with $2+1$ model. Two experts in this field scored these samples and their average scores were taken for analysis. A third expert continued to score it if the same sample was not scored within the discussed standard, and the final score for analysis would be determined by those two that are the most closest to each other. Secondly, the use of GM and its subcategories in these translating samples were numbered by the two experts together. $\mathrm{GM}=$ ideational metaphor + interpersonal metaphor + textual metaphor. Finally, the analyzing data were prepared. Final analyzing data $=$ total number of the use of GM and its subcategories $\div$ total sentences of the translating samples $\times 100$.

\subsection{Analysis}

The correlation and difference between GM and its subcategories and the translating quality were analyzed with the help of SPSS 17.0. While comparing their correlation, the partial correlation analysis was adopted. Rating levels about the grammar and vocabulary in these Chinese to English translating samples were regarded as the control variable, and the number of GM and its subcategories used in these translating samples were taken as the dependent variables. Independent sample T-test was used to analyze the difference of the uses of GM and its subcategories between learners of different levels. The uses of GM and its subcategories was the dependent variable and the classification of undergraduates and postgraduates was the grouping variable. While analyzing these data with independent sample T-test, Test of homogeneity of variance was also carried out.

\section{Results and discussion}

\subsection{Correlation of Uses of GM and Its Subcategories and the Translating Quality}

As far as learners of different proficiency are concerned, the correlation of the data of GM and its subcategories and those of the assessment of translating quality is compared (see Table 1). The table showed that GM and translating quality were significantly and positively correlated (undergraduate: $\mathrm{r}=.422, p<.05$; postgraduate: $\mathrm{r}=.521, p<.01)$. Concerning ideational metaphor, interpersonal metaphor and textual metaphor, only ideational metaphor and translating quality are significantly and positively correlated among undergraduates $(\mathrm{r}=.491, p<.05)$. interpersonal metaphor, textual metaphor and translating quality are not significantly correlated. However, the GM subcategories and translating quality are extremely or significantly and positively correlated except textual metaphor among postgraduates ( Ideatioal metaphor: $\mathrm{r}=.512, p<.01$; Interpersonal metaphor: $\mathrm{r}=.380, p<.05$ ).

Table 1. Partial correlation analysis of GM and subcategories and the translating quality (linguistic competence as the control variable)

\begin{tabular}{lllll}
\hline & GM & Ideational metaphor & Interpersonal metaphor & $\begin{array}{l}\text { Textual } \\
\text { metaphor }\end{array}$ \\
\hline $\begin{array}{l}\text { Translating quality } \\
\text { (undergraduates) }\end{array}$ & $.422^{*}$ & $.491^{* *}$ & .161 & .170 \\
$\begin{array}{l}\text { Translating quality } \\
\text { (postgraduates) }\end{array}$ & $.521^{* *}$ & $.512^{* *}$ & $.380^{*}$ & .160 \\
\hline
\end{tabular}

Note. ${ }^{*} p<.05 ; * * p<.01$. 
The fact that GM and translating quality are significantly and positively correlated among undergraduates and postgraduates, showed that the use of GM is helpful for the scoring of translating quality. Firstly, the significant correlation of ideational metaphor and translating quality among both levels of participants demonstrated that they were capable of applying ideatioanal metaphor to translation, because ideational meaning is construed by experience through meaning. Secondly, ideational metaphor suffices to meet the diversified demands of translation, i.e. all participants are capable of putting sequences into figures and figures into elements. Finally, participants in many cases translated process (represented by verbal phrases) into participants or circumstance (represented by nominal phrases), thus, the use of ideational metaphor also caters to the conversion of word classes in translation.

As to interpersonal metaphor, only postgraduates' translations and their translating quality are positively and significantly correlated. Further analysis to their translated sentences showed that the use of interpersonal metaphor was mainly concerning modalization, which demonstrated that postgraduates were more capable of expressing modal sentences.

\subsection{Differences of the Uses of GM and Subcategories in Translating Samples between English Learners of Different Proficiency}

Taking the use frequency of GM and its subcategories into consideration, those numbers between learners of different proficiency are analyzed (see Table 2). The table also shows that the mean of the uses of GM and its subcategories in postgraduates is higher than those in undergraduates. It also shows that, except textual metaphor, differences of the uses of GM, ideational metaphor and interpersonal metaphor between postgraduates and undergraduates are extremely significant $(\mathrm{GM}: \mathrm{t}=-3.170, p=.002<.01$; ideational metaphor: $\mathrm{t}=-2.945$, $p=.005<.01$; interpersonal metaphor: $\mathrm{t}=-3.750, p=.000<.01)$.

Table 2. Independent sample T-test for the uses of GM and subcategories in translating samples between English learners of different proficiency

\begin{tabular}{|c|c|c|c|c|c|c|c|}
\hline & \multicolumn{2}{|c|}{ Undergraduates } & \multicolumn{2}{|c|}{ Postgraduates } & \multirow[t]{2}{*}{ df } & \multirow[t]{2}{*}{$\mathrm{t}$} & \multirow[t]{2}{*}{$p$} \\
\hline & Mean(S.D.) & $\mathrm{N}$ & Mean(S.D.) & $\mathrm{N}$ & & & \\
\hline GM & $10.80(4.951)$ & 30 & $14.60(4.312)$ & 30 & 58 & -3.170 & $.002 * *$ \\
\hline Ideational metaphor & $6.27(3.073)$ & 30 & $8.33(2.039)$ & 30 & 58 & -2.945 & $.005 * *$ \\
\hline Interpersonal metaphor & $1.93(.852)$ & 30 & $3.40(1.793)$ & 30 & 50 & -3.750 & $.000 * *$ \\
\hline Textual metaphor & $2.60(1.404)$ & 30 & $2.87(1.383)$ & 30 & 58 & -.741 & .462 \\
\hline
\end{tabular}

The significant difference of the uses of GM, ideational metaphor and interpersonal metaphor between the two levels of participants shows not only the improvement of English language skills and the accumulation of linguistic knowledge are important to the uses of GM and its subcategories, but also the uses of GM and its subcategories embodies English learners' translation competence.

\section{Conclusion}

The correlation of GM especially ideational metaphor and translating quality between learners of different proficiency demonstrates the fact that it facilitates scoring translating quality if English learners are capable of using GM and its subcategories more precisely; meanwhile, it also provides insight to the change of learners' translation competence while translating from Chinese to English. What's more, the correlation between GM especially ideational metaphor and translation from Chinese to English should be highlighted by English teachers, and made to help them construct pedagogic structures. Furthermore, the difference of GM and its subcategories between learners of different proficiency provides proofs to English learners whether and how to develop translation competence; at the same time, it shows that the use of GM also depends on the learners' improvement of linguistic competence. Finally, we suggest that the correct use of GM in translation be one of the most important standards to score translating quality from Chinese to English.

\section{References}

Baker, M. (1990). In Other Words: A Coursebook on Translation. London: Routledge/ Beijing: Foreign Language Teaching and Research Press.

Banks, D. (2003). The evolution of grammatical metaphor in scientific writing. In A. Vandenbergen, M. Taverniers, \& L. Ravelli (Eds.), Grammatical Metaphor: Views from Systemic Functional Linguistics (pp. 
37-65). Amsterdam: John Benjamins Publishing Co. http://dx.doi.org/10.1075/cilt.236.07ban

Bell, R. T. (1991). Translation and Translating: Theory and Practice. London: Longman/Beijing: Foreign Language Teaching and Research Press.

Byrnes, H. (2009). Emergent L2 German writing ability in a curricular context: A longitudinal study of $\begin{array}{llll}\text { grammatical metaphor. Linguistics and } & \text { Education, }\end{array}$ http://dx.doi.org/10.1016/j.linged.2009.01.005

Derewianka, B. (1995) Language development in the transition from childhood to adolescence: the role of grammatical metaphor. Ph.D. dissertation, Macquarie University.

Galve, I. G. (1998). The textual interplay of grammatical metaphor on the nominalizations occurring in written medical English. Journal of Pragmatics, 30(3), 363-385. http://dx.doi.org/10.1016/S0378-2166(98)00002-2

Halliday, M. A. K. (1985). An Introduction to Functional Grammar. London: Arnold.

Halliday, M. A. K. (1993). Some grammatical problems in scientific English. In M. A. K. Halliday \& J. R. Martin (Eds.), Writing Science: Literacy and Discursive Power (pp. 69-85). London: Falmer.

Halliday, M. A. K. (1994). An Introduction to Functional Grammar. London: Edward Arnold.

Halliday, M. A. K. (1998). Things and relations: regrammaticising experience as technical knowledge. In J. R. Martin \& R. Veel (Eds.), Reading Science: Critical and Functional Perspectives on Discourses of Science (pp. 185-236). London: Routledge.

Halliday, M. A. K., \& Matthiessen, C. M. I. M. (1999). Construing Experience through Meaning: A Language-based Approach to Cognition. London: Cassell.

Halliday, M. A. K., \& Matthiessen, C. M. I. M. (2004). An Introduction to Functional Grammar. London: Edward Arnold.

Hatim, B., \& Mason, I. (1990). Discourse and the Translator. London: Longman/Shanghai: Shanghai Foreign Language Education Press.

Huang, G. W. (2006). Linguistic researches on translation studies. Shanghai: Shanghai Foreign Languages Education Press.

Huang, G. W. (2009). The application of grammatical metaphors in translation studies. China Translation, 1, 5-9. Retrieved from http://en.cnki.com.cn/Article_en/CJFDTOTAL-ZGFY200901003.htm

Liu, C. Y. (2007). Functions of grammatical metaphor-cognitive stylistic studies. Doctoral dissertation, Sun Yat-sen University. Retrieved from http://www.cnki.net/kcms/detail/detail.aspx?dbname $=$ CDFD2008\&filename $=2008057433 . n h \& v=M j M 5 M z$ ZVTHZJVjEyN0ZyTzlHZFhQckpFYIBJUU9EUTg4dkJabTdFcC9UMzZSMmhveEZyQ1VSTCtlWmVSb $\mathrm{UZDdmc}=$

Painter, C. (2003). The use of a metaphorical mode of meaning in early language development. In A.-M. Simon-Vandenbergen, M. Taverniers, \& L. J. Ravelli (Eds.), Grammatical Metaphor: Views from Systemic Functional Linguistics (pp. 151-168). Amsterdam: Benjamins. http://dx.doi.org/10.1075/cilt.236.04rav

Ravelli, L. J. (1985). Metaphor, mode and complexity: an exploration of co-varying patterns. BA Honours thesis, University of Sydney.

Ravelli, L. J. (2003). Renewal of connection: integrating theory and practice in an understanding of grammatical metaphor. In A.-M. Simon-Vandenbergen, M. Taverniers, \& L. J. Ravelli (Eds.), Grammatical Metaphor: Views from Systemic Functional Linguistics (pp. 37-64). Amsterdam: Benjamins. http://dx.doi.org/10.1075/cilt.236.04rav

Thompson, G. (2004). Introducing Functional Grammar (2nd ed.). London: Arnold.

Torr, J., \& Simpson, A. (2003). The emergence of grammatical metaphor: Literacy-oriented expressions in the everyday speech of young children. In A.-M. Simon-Vandenbergen, M. Taverniers, \& L. J. Ravelli (Eds.), Grammatical Metaphor: Views from Systemic Functional Linguistics (pp. 169-183). Amsterdam: Benjamins. http://dx.doi.org/10.1075/cilt.236.10tor

Wang, D. F. (2006). Functional linguistics and translation studies. Guangzhou: Sun Yat-sen University Press.

Yang, W. X., \& Sun, Y. (2012). The use of cohensive devices in argumentative writing by Chinese EFL learners at different proficiency levels. Linguistics and Education, 23, 31-48. 
http://dx.doi.org/10.1016/j.linged.2011.09.004

Yang, Y. N. (2008). Typological interpretation of differences between Chinese and English in grammatical metaphor. Language Sciences, 30, 450-478. http://dx.doi.org/10.1016/j.langsci.2007.01.007

Zhou, J. P. (2010). A comparative study on the language production of personal experience narratives and working memory. MA thesis, Southwest University. Retrieved from http://www.cnki.net $/ \mathrm{kcms} /$ detail/detail.aspx?dbname=CMFD2010\&filename $=2010121296 . \mathrm{nh} \& \mathrm{v}=\mathrm{MTI} 4 \mathrm{Mz}$ VnVzcvSIYxMjZIcks2SDIQRnFaRWJQSVFPRFE4OHZCWm03RXAvVDM2UjJob3hGckNVUkwrZVpl $\mathrm{Um} 1 \mathrm{GQ} 3 \mathrm{Y}=$

\section{Copyrights}

Copyright for this article is retained by the author(s), with first publication rights granted to the journal.

This is an open-access article distributed under the terms and conditions of the Creative Commons Attribution license (http://creativecommons.org/licenses/by/3.0/). 